\title{
University Practice As A Key Factor In Increasing The Sensitivity To Educational Inclusion
}

\author{
Laura E. De Luna Velasco, University CUSUR, Mexico \\ Antonio Hernández Fernández, Ph.D. University of Jaen, Spain \\ Isabel María Ferrándiz Vindel, Ph.D. University of Castilla La Mancha, Spain
}

\begin{abstract}
The present article is based on research carried out in three universities, the University Center South (Cusur, Mexico), Jaen and Cuenca (Spain) on the influence of university practice in the development of sensitivity towards inclusive education in our students the first years of the Diploma in Education, using the subject "pedagogical basis of special education" and the equivalent Cusur and Cuenca. With the idea that the practices of the subject are the ideal time to promote positive attitudes towards inclusive education a questionnaire to collect data prior to the four month long activities focused on the presentation of case studies and program auditions radio "A Light in the Chest" which airs on Ciudad Guzman (Mexico) directed by Professor De Luna and which revolves around the inclusion. When the semester ended he turned to pass the quiz to test variations in sensitivity to educational inclusion or not been able to develop our university students.
\end{abstract}

Keywords: Sensitivity; Educational Inclusion; University Practice

\section{INTRODUCTION}

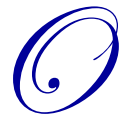

ur education system is undergoing a continuous process of change as people make it vary, relying on an inclusive and integrative University, which will mean a major transformation methodologies, assessment, content, etc... And of course a change the mindset of the entire university community. In addition, this system must meet the needs arising from each of the individuals that form, ie it must take into account the individual characteristics of each of the people involved in the teaching and learning at all levels of our university system (Simon and Albert, 1989)

No longer seeks the student self-enclosed and its cognitive power but is intended to be capable, with a strong theoretical support, attitudinal skills acquisition. Therefore in the new space is to promote higher education among students new ways of relating which aim to ensure information sharing between them, knowing that this means train their peers to understand, to acquire "other experiences" without this incurring any threat.

In our universities are subjects that have the dual aspect theory and practice, as we understand the need for practice as an approach to reality. In this study we began an analysis of the influence of university practical activities to develop sensitivity to the educational inclusion of the first students courses careers in Education (Pedagogy, Psychology, Early Childhood Education, Elementary Education, Education Social ...), taught at the University of Jaén (Spain), University of Castilla La Mancha (Spain) and CUSUR (Mexico).

The initial idea is that the practices of a subject are the ideal time to promote positive attitudes towards inclusive education, so we decided to make a questionnaire to collect data on progress in the sensitivity towards inclusive education have been or not develop our college students throughout the school year of our subjects. As a practical methodology in each center pose different practical activities to see what can be more rewarding in this 
process: tasks focused on the presentation of case studies, auditions radio specific programs, such as "A light in the trunk" which airs on Ciudad Guzman (Mexico), organization of awareness workshops ....

But what do we mean by Inclusive Education?

The concept of inclusive education was adopted at the "World Conference on Special Needs Education: Access and Quality", held in Salamanca, Spain, in 1994. This term is used to refer to the integration of people with disabilities to mainstream education. This implies the implementation of specific measures and actions to regular schools meet the special educational needs. Inclusive education as a concept in itself is covered in the law that all children have to receive a quality education with equal opportunity and nondiscrimination. (Essomba, 2006)

Cuomo and Imola (2008) review the experiences, contexts and situations, ways to teach, and so on. Research of educational experiences, they say, is to be done from a didactic orientation, as an inclusive educational intervention cannot be focused in the amount of knowledge but has to propose autonomy to act in the know.

Bunch (2008) says that the inclusion of disabled students who experience challenges the traditional reliance on segregated education. Under the leadership of the United Nations and a growing number of nations, inclusive education is making a global impact.

The Classroom and School Practice project of the European Agency focuses on developing, analyzing, describing and disseminating classroom practices apparently successful in inclusive settings. As stated Meijer (2009), this project attempts to answer key questions relating to inclusive education, what practices have proven effective in inclusive education? This shows that there is a concern in the international arena to find out the keys that define successful inclusive settings.

Address the practice from epistemological point of view becomes a complex exercise because of the diversity of views that exists on it. In our daily practice as university professors, we found that the type of practices that are performed often determine shifts in the conception of some realities.

Therefore, we have considered more sensitive towards inclusive education by changing the methodology of our business practices.

But, what do we mean by sensitivity?

From latin sensibilitas, sensitivity is the ability to feel (typical of sentient beings and animated). The term takes on different meanings according to context.

The sensitivity may be the natural human tendency to drift affects the tenderness and compassion. For example: "The picture of a malnourished child awakened my sensibility and decided to collaborate," "My husband does not like those films, seems to have no highly developed sensitivity," "To work in the hospital should be allowed the sensitivity of side and not engage emotionally with patients. "

In everyday language the word "sensitivity" refers to the ability to take moral and aesthetic values, but this expression Kantian philosophy means the power to have feelings, although not very accurate, we can identify with perception. Sensitivity Sensitivity is divided into internal and external sensitivity, the sensitivity is the inner inner perception, ie the ability to have immediate knowledge, direct one's own psychic life, as when we know we are sad or that we are remembering or thinking; External Sensitivity is the external perception, ie the ability to have immediate knowledge of physical objects, as when we see a table or hear a song. Space and time are a priori forms of external sensitivity, and time is the a priori form of internal sensitivity. (Ainscow, 2001)

The term sensitivity is used in other contexts to mean issues that have nothing to do with the strictly physical. Then, sensitivity also is the natural tendency we humans have emotions or feelings, so when a person usually moved very easily to certain circumstances that involve or keep a strong emotional commitment, they say that person holds increased sensitivity. (Arnaiz, 2003) 
Inclusive education requires, in our opinion, a degree of sensitivity: see the differences, assessing disability, see the diversity requires sensitivity.

\section{METHODOLOGY}

The reason that leads us to conduct the study on the increased sensitivity to the inclusion in the university, for several reasons, among them we highlight:

- There are few experiments on the analysis of practices in university students.

- The use of a questionnaire can help us to know and understand better the improvement in the involvement of inclusion.

- Offers opportunities to identify what activities are more conducive to increased sensitivity.

The objective of this study is to analyze practices in three universities (CUSUR of Mexico, Jaen and Castilla-La Mancha, Spain) are being carried out with students of careers in education, in subjects in the field of Special Education using a questionnaire with indicators that reflect whether university practices are key to the increased sensitivity towards inclusive education.

To carry out our study, we chose to use a questionnaire as a tool for data collection. Questionnaire mean by "a group more or less broad, questions or issues that are considered relevant for the trait, characteristic or variables that are the subject of study" (Bisquerra, 1996).

The reference sample consists of one group of students from the Faculty of Education at the University of Jaén, all enrolled in the subject of Special Education Pedagogical Bases.

\section{RESULTS}

A questionnaire has been obtained of sensitivity to the inclusion consists of 30 items, with an overall reliability of 0.81 . [See Table 1].

Table 1.

Estadísticos de fiabilidad

\begin{tabular}{|r|r|}
\hline $\begin{array}{c}\text { Alfa de } \\
\text { Cronbach }\end{array}$ & \multicolumn{1}{|c|}{$\begin{array}{c}\text { N de } \\
\text { elementos }\end{array}$} \\
\hline, 818 & 30 \\
\hline
\end{tabular}

For our guest we will use the content validity. To do this, we have relied on "expert judgment" and "a pilot". Its validity was done by taking a group of experts and making the corresponding judgment. There are eight professionals, 4 teachers, specialists, and 4 teachers from the Universities of Jaén, Granada, Seville and CUSUR.

Was performed for pilot, noting that the questionnaire has a valid right.

The analysis of questionnaires and subsequent statistical analysis using SPSS, seeks to analyze whether the results of the first pass show a significant difference or not the results it gives the second pass, we analyze the $\mathrm{T}$ Student test.

We obtain a significance with Student's T in questions 2, 3, 8, 9, 10 -> 19, 21 -> 27, 30

The increased sensitivity is observed in relation to training in professional areas related to special education (teachers and psychologists), the information held on pupils with different disabilities, the importance of knowing the characteristics to be able to respond appropriate, it is also important to know the characteristics that have a family with a disabled student, the good news to know to make an ICA, and the essential question that the class practices increase the sensitivity to people with disabilities. It should be noted that the topics covered in the radio program "A light in the trunk" are the most sensitive awoke. 
No significant increase in sensitivity in subjects such as lectures that increase the sensitivity, that inclusive education is important for the educational system, and interesting is that they think that no stray radio or print information about the world of disability.

\section{CONCLUSIONS}

The main objective of this work is the construction of a valid and reliable questionnaire to assess the increased sensitivity in future professionals in education.

This questionnaire presents, from the viewpoint of the authors, a better adaptation to the group studied, as each university presents a variety of capacities to obtain a higher priority than others.

Through this work we wanted to check, too, that since the university practice can be selected and used consciously, activities closer to the world, society ... that serve to transform reality.

After this initial study, we found that some college students acquire skills such practices that pose alternative solutions to certain problems, still not knowing what will be the true and real solution for every situation. But undoubtedly, the practice should not be seen as a single component, but for better understanding, needs to be looked in relation to the theory.

\section{AUTHOR INFORMATION}

Laura E. De Luna Velasco, Degree in Psychology. Teacher CUSUR. Research Interest: inclusive education of disabled people.

Antonio Hernández Fernández, Ph.D. and Degree in Pedagogy by University of Granada. Research Interest: inclusive education of disabled people. E-mail: ahernand@ujaen

Isabel $\mathbf{M}^{\mathbf{a}}$ Ferrándiz Vindel, Ph.D. and Degree in Education Sciences by Complutense University of Madrid (UCM), Spain. Professor at the Pedagogy Department. Faculty of Education Sciences and Humanities of Cuenca. University of Castilla-La Mancha (Spain). Research Interest: inclusive education of disabled people. E-mail: Isabel.Ferrandiz@uclm.es (Corresponding author)

\section{REFERENCES}

1. Ainscow, M. (2001). Desarrollo de escuelas inclusivas. Ideas, propuestas y experiencias para mejorar las instituciones escolares. Madrid: Narcea.

2. $\quad$ Arnaiz, P. (2003). Educación inclusiva una escuela para todos. Málaga: Aljibe.

3. Bunch, G. (2008). "Keys to successful inclusive education: A perspective from experience in the field." Revista de Educación Inclusiva, vol. (1), nº 1, pág. 91-101.

4. Cuomo, N., Imola A., (2008). “Análisis del contexto y las formas de enseñar". Revista de Educación Inclusiva, vol. (1), no 1 , pág. 49-58.

5. Essomba, M.A. (2006). Liderar escuelas interculturales e inclusivas. Equipos directivos y profesorado ante la diversidad y la inmigración. Barcelona: Grao.

6. $\quad$ Meijer, C.J.W. (2009). European convergence. Revista de Educación Inclusiva, vol. (2), n², pág. 53-60.

7. Sánchez, A. y Torres, J.A. (2002). Educación Especial. Centros educativos y profesores ante la diversidad. Madrid: Pirámide.

8. Simon, P. y Albert, L. (1989) Las relaciones interpersonales: ejercicios prácticos y fundamentos teóricos. Barcelona: Herder.

9. Stainback, S.W. (1999). Aulas inclusivas. Madrid: Narcea.

10. UNESCO (1977). La educación especial. Situación actual y tendencias en la investigación. Salamanca: Sígueme.

11. Warnock, H.M (1978). Report of the committee of Enquiry into the Education of Handicapped children and young people. London: Her Majesty's Stationery Office. 